\title{
UNDERGROUND FACILITIES IN MODERN CONFLICTS
}

\author{
Daniel SOLESCU \\ "Nicolae Bălcescu" Land Forces Academy, Sibiu, Romania \\ danielsolescu@yahoo.com
}

\begin{abstract}
Knowledge of the nature and location of underground facilities is of great value to both the urban attacker and defender. To exploit the advantages of underground facilities, a thorough reconnaissance is required. This papers describes the role of underground facilities in military actions in urban areas
\end{abstract}

\section{Keywords: subterranean operations, underground facilities, urban operations}

\section{Introduction}

Since ancient times, people have shown a great interest in building various underground facilities, primarily tunnels, mainly used for military purposes. Tunnel construction was part of the defense and, ultimately, the evacuation strategy of the population, facilitating the escape of people in the event of a siege against the city.

At the same time, the tunnels were one of the few means of penetrating inside the fortifications, a classic example being the battle to conquer Byzantium, where the Turks tried to penetrate the city by digging tunnels under the walls. The defenders dug counter-tunnels, allowing the Byzantine troops to enter and kill the Turkish engineers, or to flood the tunnels.

With the advancement of combat techniques and weapons, the tunnels have not lost their "charm" or the defense roles, but they have been replaced by bunkers that represent a shelter with almost all medium and long-term living conditions.

In the current security context, underground facilities are best suited to provide adequate protection against increased power weapons such as cruise missiles, guided rockets and self-propelled missiles, boxes with self- propelled ammunition on the last part of the trajectory, weapons of mass destruction, etc.

The tactics of using underground facilities adapted or executed directly for military purposes, as well as the military actions in these locations, has not been approached systematically, as far as we know, in our battle textbooks, and there is only one appendix in the textbook of operations in urban environment for infantry subunits.

For these reasons, our attempt to systematically approach the use of underground facilities in carrying out military and resistance operations in case of invasion has a novel character.

\section{Conceptual delimitations}

There are numerous definitions of underground facilities in the literature (regulations, instructions, manuals). A first definition mentions that underground engineering facilities are deep excavations (galleries), with a protective layer of at least 10 meters, for sheltering personnel or special equipment, for connection, communication or for carrying out the warfare (reaching through the galleries under enemy positions, mining and 
throwing them into the air) [1]. Generalizing, underground facilities are those constructions (tunnels, galleries, hideaways, communications, civil and technological works) with natural ceilings of protection and hiding built in peacetime or during the preparation and carrying out of combat actions, or arranged from the existing ones, according to certain tactical necessities and which, occupied with forces and means of fire and used in a unitary conception, represent strong points of resistance.

In the category of underground facilities, we may include: caves, grottos, other natural underground spaces, road and railway tunnels, basements of industrial, cultural and residential constructions, subway galleries, underground passages and garages, underground channels and galleries build for public purposes, hydro-energetic constructions below ground level, etc.

The Romanian specialists [2] believe that, according to their purpose in military actions, the underground facilities can be classified as follows:

a) Underground facilities intended for direct combat. This category includes: support points, underground and surface defense districts linked together; command and observation points; connection galleries, shelters, etc.

b) Underground facilities for assurance of combat activities, including secret access routes to the enemy and returning to its own; facilities for sheltering combat technology; facilities for the execution of the decontamination of the military staff and the combat technique.

c) Underground facilities for the needs of logistics, comprising: deposits with different purposes, such as medical purposes or hospitals, weapons and ammunition factories.

\section{The role of underground facilities in military actions in urban areas}

The inclusion of urban centers, irrespective of size, in the military action system is justified by the high military potential they have. In cities there are subway lines, utility tunnels, sewage tunnels or pluvial drainage, garages and underground passages. These hidden and protected facilities allow the troops to move inside without being detected. Knowing in detail the nature and location of these underground facilities is of great importance both for the attacker and especially for the defender. The full use of these underground facilities can be a decisive factor in the course of a conflict in an urban area.

The offensive actions in urban centers are influenced by the following factors: their size and configuration; the geographic characteristics of the land where they are located; the quality and density of constructions; the existence of underground facilities; the number of civilian population; their political and economic importance; the existence, value and outcome of urban resistance actions.

In the offensive, the underground facilities are used for:

- assault actions (movement and surpriseattack or underground access to the target);

- demining and removing existing explosive devices at some targets;

- accommodating troops and placement of control points;

- moving safely and secretly between neighborhoods, streets or buildings.

The integration of urban centers in defense contributes to increasing its stability and firmness on a tactical or operative level, territorial or zonal, as the case may be, and depends on the particularities of each locality, determined by: the geographical characteristics of the land on which they are located, the size, the configuration, and the extent of housing districts, the density of 
streets, the durability and density of buildings, the number and size of the watercourses that cross them.

Due to the degree of protection they provide, by secretly placing the troops, combat equipment, the underground facilities are an essential subsystem of overall engineering part of the defense.

The analysis of the use of underground spaces for defense purposes should be done for each urban area in order to optimally adapt the constructive parameters, individualized to the most appropriate destination or which is required in certain situations and which exploits both the constructive elements and the concrete tactical needs that result from the way of organization and preparation of combat.

This analysis must be carried out during peacetime, in order to determine the measures to be taken for their proper use according to the needs of the combat, but also to determine the initial constructive features and to adopt measures for their consolidation.

The underground facilities are also crucial in the resistance actions in urban areas occupied by the enemy. The underground resistance fight will be organized and conducted in urban centers and nearby areas where there are such facilities as: tunnels and underground galleries, abandoned mine galleries, caves, large collector channels, district heating galleries, underground passageways between blocks and residential neighborhoods or economic, administrative, industrial, or cultural targets.

As a rule, underground there will be small troop formations. The small number of these resistance formations is determined by:

- the spatial dimensions of the underground facilities to be used;

- inadequate living conditions (lack of ventilation, moisture, toxic gas emissions) requiring the use of individual protective means (oxygen or gas masks, special clothing and footwear), special lighting, means of water and underwater transportation (boats, individual swimming suits).

In our opinion, the underground facilities can be used in urban resistance as follows:

- as temporary or permanent shelters for soldiers, after prior arrangements have been made for their development and internal consolidation and the provision of a security and alert system, as well as several entries and exits in the fox-style den.

- as places of assemble of groups of soldiers, before or after the accomplishment of combat missions;

- for the secret movement or maneuvers between different neighborhoods of the city or for approaching the target to be attacked;

- to break up the fight or to withdraw after the mission had been completed;

- for the transport of weapons, ammunition and equipment from clandestine deposits or to and between resistance formations;

- for arranging workshops, warehouses, hospitals that support the resistance movement;

- to interrupt electricity, water and gas;

- for secretly entering the enemy forces' buildings to carry out direct or sabotage actions.

\section{Conclusions}

In conclusion, due to the complexity of the designing and building of underground facilities of all kinds, the specific technology and equipment needed for military purposes, as well as the tactical considerations, it is necessary that the use of the underground facilities be carefully studied and solved during peacetime.

The matters presented in this article still require military specialists to undertake new investigative efforts, both theoretically and practically, in order to arrive at judicious conclusions to be introduced in the specialized textbooks. 
Given the new dimensions of the battle space, a new configuration is needed to prepare the soldiers and the subunits. The accomplishment of these missions in the underground space must be studied and experienced in educational process, military exercises, so that a general model can be developed. The effort is imperative due to the multivalent functional value of the underground facilities in the $21^{\text {st }}$ century combat actions.

\section{References}

[1] Lexicon Militar, EdituraMilitară, București, 1980, p.42;

[2] Col. Octavian PUȘCHILĂ, Col. Ing. Constantin NIȚICĂ, Col. Petre GRECU, Lucrările subterane și acțiunile de luptă, Editura Militară, București, 1994, p. 49; 